УДК 314

$10.17213 / 2075-2067-2021-2-72-82$

\title{
СЕМЕЙНЫЙ ТЕЗАУРУС МОЛОДЫХ МУЖЧИН ${ }^{1}$
}

\author{
(C) 2021 г. Ч. И. Ильдарханова*, В. А. Гневашева
}
"Центр семьи и демографии Академии наук Республики Татарстан, г. Казань, Россия
** Институт демографических исследований Федерального научно-исследовательского социологического центра РАН, 2. Москва, Россия

Цель исследования обусловлена необходимостью изучения проиессов формирования тезауруса молодых отиов, молодых людей, с иелью выявления наследуемых общественных ценностных ориентиров, обоснования вероятных стратегических траекторий развития семейных, брачных и репродуктивных отношений.

Методология исследования представлена методологическими и теоретическими работами ученых, исследователей в области изучения молодежи как страты общества, а также применения тезаурусного подхода к оценке иенностных ориентаций общества. В исследовании применены методы коррелящионной оценки переменных, а также графические методы оченки параллельных данных.

Результаты исследования позволяют сделать ряд выводов о наметившихся негативных тенденциях, подрывающих сочиильно устойчивый тезаурусный концепт семьи, что требует дополнительного и более детального изучения с формированием соответствующих программ, в том числе и государственного уровня позиционирования образа семейнобрачных и репродуктивных отночений в ценностном концепте современной молодежи.

Ключевые слова: семейный тезаурус; семья; ценностные ориентащии; молодые мужчины.

\section{FAMILY THESAURUS OF YOUNG MEN}

\section{(C) 2021 Ch. I. Ildarhanova*, V.A. Gnevasheva **}

\section{"Family and Demography Center Tatarstan Academy of Sciences, Kazan, Russia *Institute of Demographic Research of the Federal Research Sociological Center of the Russian Academy of Sciences, Moscow, Russia}

The purpose of the study is due to the need to study the processes offormation of the thesaurus of young fathers, young people, in order to identify inherited social values, substantiate the likely strategic trajectories of the development of family, marriage and reproductive relations.

The research methodology is presented by the methodological and theoretical works of scientists, researchers in the field of studying youth as a stratum of society, as well as the application of the thesaurus approach to assessing the value orientations of society. The study used methods of correlation estimation of variables, as well as graphical methods for estimating parallel data.

1 Исследование выполнено при финансовой поддержке РФФИ в рамках научного проекта «Генеративное поведение российских мужчин в условиях демографического кризиса: Приволжский и Северо-Западный округа РФ (сравнительный анализ)» №19-011-00644. 
The results of the study allow us to draw a number of conclusions about emerging negative trends that undermine the socially stable thesaurus concept of the family, which requires additional and more detailed study with the formation of appropriate programs, including the state level of positioning the image of family, marriage and reproductive relations in the value concept of modern youth.

Key words: family thesaurus; a family; value orientations; young men.

Актуальность исследования. Исследование обусловлено важностью детерминации тезауруса молодых мужчин с целью выявления значимых ценностных ориентаций, предпосылок их формирования, степени развитости и направленности той или иной ценностной компоненты, степень их влияния на процессы брачного, семейного, репродуктивного поведения, а также социально-экономических реакций и изменения в семейных статусах.

Теоретические предпосылки исследования. Основные концептуальные стороны тезаурусного подхода состоят в следующем. Тезаурус представляет собой индивидуальную конфигурацию ориентационной информации (знания, нормы, ценностные ориентации, социальные установки), формируемую под воздействием внешних макро- и микросоциальных факторов, что обеспечивает определенные социальные траектории индивида на различных уровнях социализации.

Концептуальные аспекты тезаурусного подхода схожи с идеями символического интеракционизма Чикагской социологической школы [11], но в то же время в большей степени учитывают именно объективные условия формирования индивидуальных тезаурусных конструкций, в этой части имеющих в качестве сопряженного основания понятие «образ жизни, сформированный обществом», в этой связи можно говорить и о синхронизации тезаурусных конструкций. Однако индивидуальный тезаурус вовсе не обусловлен лишь процессом синхронизации, а включает также формы диахронии, которая в свою очередь предполагает перенос сквозь поколения определенных концептов с последующей их ретрансляцией или возрождением после эпох забвения.

В исследовании применяется тезаурусный подход также в оценке ценностных ориентаций гендерных сообществ (молодых мужчин). В исследовании под ценностными ориентациями понимается существенная сторона тезауруса, а именно: направленность субъекта (личности, группы, сообщества) на цели, осознаваемые им позитивно значимыми (благими, правильными, высокими и т.п.) в соответствии с принятыми в обществе (сообществе) образцами и имеющимся жизненным опытом и индивидуальными предпочтениями. При этом векторная направленность исследования определена семьей - брачным и репродуктивным поведением. Такая направленность представляет собой совокупность устойчивых мотивов, лежащих в основе ориентации субъекта в социальной среде и его оценок ситуаций. Она может осознаваться в разной степени, выражаться в фактах поведения, веры, знания и иметь форму стереотипа, суждения, проекта (программы), идеала, мировоззрения. При этом из направленности на признаваемые позитивными жизненные цели не следует автоматически активных действий субъекта по их достижению в реальной действительности [3].

Ценность по М. Веберу - это форма человеческого мышления, а также соотношение, соотнесенность человека с миром вещей, людей и духовных явлений. Весомый вклад в развитие теории ценностей внес представитель французской социологической школы Э. Дюркгейм с его понятием «аномии». Теория ценностей начала активно развиваться после Первой мировой войны в американской социологической науке. Исследования в области аксиологии в этот период были связаны с именами В. Томаса, Э. Фэриса и Дж.Г. Мида, Т. Парсонса и др.

Философское осмысление категории «ценность» восходит к работам философов XIX-XX вв. Р. Лотце, В. Виндельбанда, Г. Риккерта, А. Мейнонга, М. Шелера, Н. Гар- 
тмана, Ф. Брентано. Вклад в практику исследования ценностной проблематики осуществлен социологами У. Томасом, Ф. Знанецким, М. Вебером, Э. Дюркгеймом, Т. Парсонсом, П.А. Сорокиным, психологами М. Рокичем и Ш. Шварцем. Проблематика молодежных ценностей рассмотрена в рамках теории социального наследования К. Манхеймом, в рамках концепции межпоколенных отношений - М. Мид.

Важно отметить общероссийские исследования ценностей и ценностных ориентаций Института философии РАН, Института социологии РАН, Института психологии РАН $[7,8,9]$.

Особо отметим цикл исследований, проведенных под руководством доктора философских наук Н.И. Лапина [2], а также международные сравнительные исследования под руководством М. Г. Руднева и В.С. Магуна [4]. Модернистское направление в исследованиях ценностных ориентаций связано с именем Р. Инглхарта и с международным проектом [1]. Основные тематические направления в отношении изучения тезаурусных концептов разных страт общества отражены в исследованиях обоснования тезауруса социологии [7], феномена российского общества и тенденций стратовых ценностных изменений [8], эмпирических оценок социального портрета молодежи [5], определения социально-культурных факторов национальной безопасности [6], определения идентичности в условиях нелинейной социальнокультурной динамики [9], образовательных и профессиональных траекторий российской молодежи [10] и др. Вместе с тем отдельные направления тезаурусного формирования с детерминантой более мелких по объему стратовых компонент требуют более детального, регионального, дифференцированного обоснования.

Методология исследования. В эмпирическом исследовании, проведенном в Республике Татарстан и Вологодской области РФ под руководством Ч.И. Ильдархановой в рамках реализации научного проекта «Генеративное поведение российских мужчин в условиях демографического кризиса: Приволжский и Северо-Западный округа РФ (сравнительный анализ)» №19-011-00644 при финансовой поддержке РФФИ, приняли участие 1353 респондента (мужчин). Задачи исследования состоят в выявлении типологии поведения молодых мужчин в отношении семейных, брачных и репродуктивных ценностных ориентаций, а также формирования ими социально-экономических реакций и соответствующих моделей семейного тезауруса.

На долю молодежного сегмента (от 18 и до 32 лет) в выборке приходится $31,7 \%$ респондентов. Мода распределения - возрастная группа «33-37 лет».

Чуть менее половины респондентов определили себя как верующих $(49,2 \%)$, треть - отметили отрицательную позицию (32,7\%). Наибольшая доля верующих отмечается в возрастной группе «38-42 года», в этой же возрастной группе отмечается и наименьшая доля неверующих - 25,3\%, в противоположность наибольшая доля неверующих представлена в возрастной группе «18-22 года» - 48,1\%. Из опрошенных ислам в большей степени разделяют в возрасте 33-37 лет (23,4\%), христианство — в возрасте 38-42 года $(16,5 \%)$, иные религии - в возрасте $38-42$ года (28\%).

При этом также чуть менее половины сказали, что «веруют, но обрядов не совершают» $(48,7 \%$, в возрастном распределении это преимущественно группа «18-22 года» (55,9\% по возрастной группе)), и только каждый пятый отметил, что верует и посещает церковь (мечеть) регулярно $(21,3 \%$, в возрастном распределении это преимущественно группа « $48-52 »$ года $(27,9 \%)$ и группа « $43-47$ лет» $(20,8 \%))$.

По профессионально-образовательному уровню можно отметить две доминантные группы: специалисты на работах, требующих высшего образования $(28,0 \%)$, и работники по специальностям, требующим среднего специального образования $(18,1 \%)$, преимущественно занятые в промышленности $(25,6 \%)$ и строительстве $(16,5 \%)$, работающие в основном ежедневно полный рабочий день (68\%), как правило, в одном месте вне дома $(78 \%)$ в объеме 40 часов $(35,8 \%)$, реже - $48(9,4 \%)$ и 50 часов $(10,8 \%)$.

При этом уровень среднемесячной заработной платы сосредоточен в трех доминантных группах: 10000-19999 рублей $(18,0 \%), 20000-29999$ рублей $(25,7 \%)$, 
30000-39999 рублей (21,1\%). В отношении своей супруги/партнерши респонденты отметили, что она преимущественно работает (59,2\%), однако 20,5\% все же остаются дома, не работают. Среди работающих, как правило, занятость составляет 40 часов в неделю $(35,7 \%)$, но есть доля и тех, кто занят более этой нормы - 27,3\% работают более 40 часов в неделю.

По социальному статусу 59,5\% респондентов относят себя к «среднему классу», 26,6\% - «ниже среднего класса».

Каждый четвертый респондент $(25,3 \%)$ абсолютно согласен с утверждением, что дело мужчины - зарабатывать деньги, а дело женщины - справляться с делами по дому и воспитывать детей. 36,6\% респондентов, отвечая на данный вопрос, выбрали позицию «в чем-то согласен, а в чем-то нет». Но в целом более-менее согласны с данным утверждением более $2 / 3$ респондентов.

В целом по временным затратам на домашнее хозяйство и воспитание детей в представлениях респондентов оптимальный объем затрат времени - 1 час, супруга/партнерша - чуть в большей степени, с их точки зрения, в вопросах домашнего хозяйства и воспитания детей - с доминантной позицией участия 2-3 часа.
В распределении по семейному статусу более половины состоят в зарегистрированном в ЗАГСе браке; $10,5 \%$ - состоят в незарегистрированном браке; 9,5\% - холосты и никогда не были женаты; тех, кто ответил, что на данный момент разведен, - 6,5\%. В возрастном распределении можно отметить преимущественную регистрацию брака в возрастных группах «33-37 лет» $(20,2 \%)$ и «38-42 года» $(17,9 \%)$, причем темпы активности в регистрации брака существенно увеличиваются с 28 лет $(0,8 \%$ регистрирующих брак в возрастной группе «18-22 года», 4,6\% - «23-27 лет», $12,5 \%$ - «28-32 года»). Численность разведенных особенно фиксируется в возрастной группе «38-42 года» $(20 \%)$, а также в группах «43-47 лет» $(15,6 \%)$ и «3337 лет» (15,6\%). Две трети респондентов имеют собственных (кровных) детей $(67,6 \%$, возрастной пик наличия собственных, кровных детей приходится на возрастную группу «33-37 лет» (19,0\%)), четверть из опрошенных детей не имеют $(24,1 \%), 6,5 \%$ - проживают совместно с детьми их супруги/партнерши (при этом на возрастную группу «3337 лет» приходится 24,4\% воспитываемых детей супруги/партнерши, а на возрастную группу «38-42 года» - 35,0\% официально усыновленных).

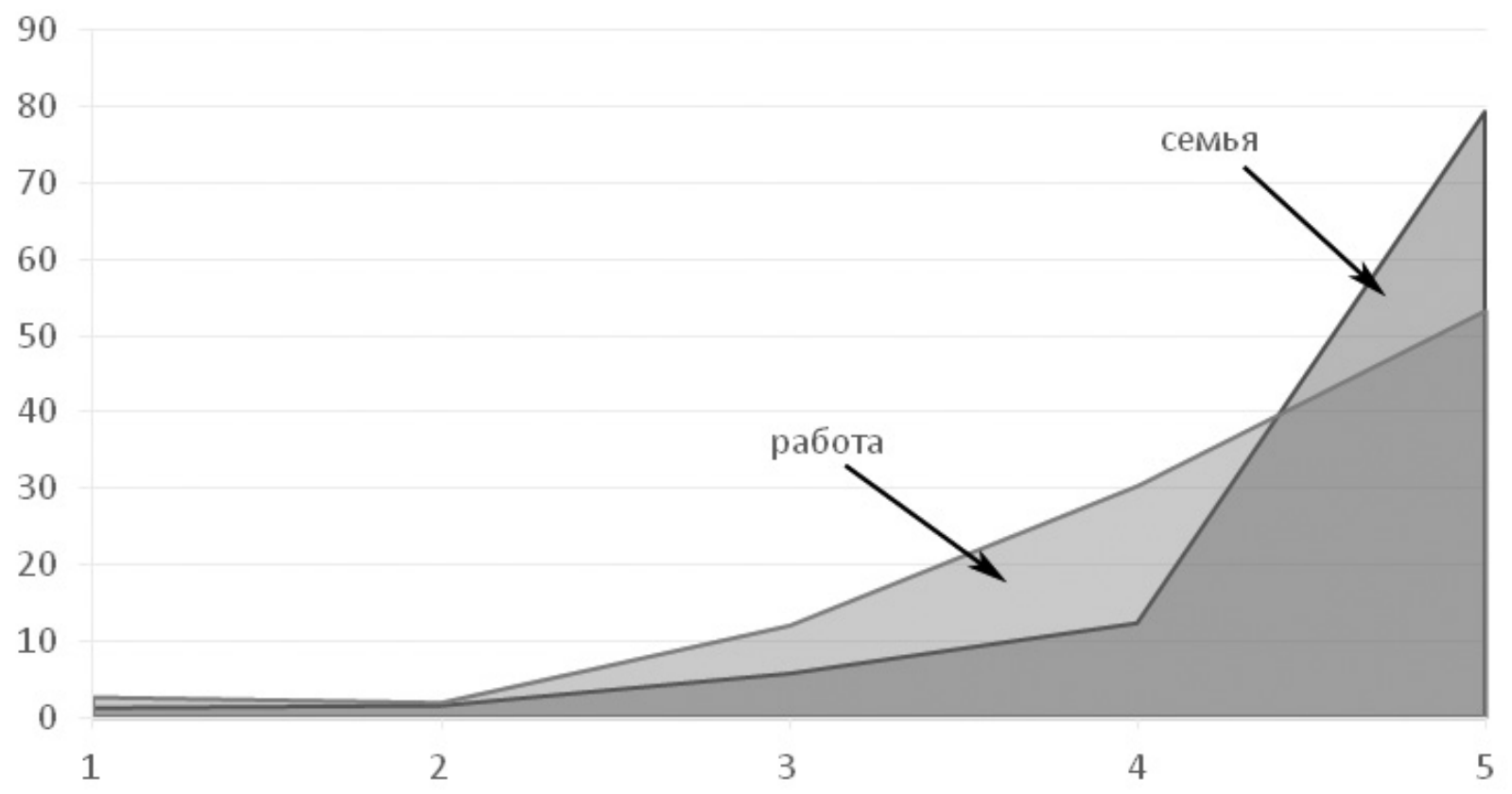

Рис. 1. Оценки респондентами важности работы и семьи по пятибалльной шкале (1 - наименьшая ценность, 5 - наивысшая ценность) (в \%) 
Из ответов респондентов видно, что подавляющее большинство приветствует проживание совместно с собственными детьми $(79,5 \%)$, хотя определяется еще одна значимая группа - примерно каждый десятый из отвечавших сказал, что дети проживают с другими родственниками (11\%).

Оценивая значимость семьи в семейном тезаурусе респондентов, важно провести сравнение определения ими степени значимости работы и семьи в сопоставимых оценках. Оцениваемые позиции характеризуются стабильной значимостью работы и маркерной значимостью семьи в отношении абсолютной позиции - 5 баллов (см. рис. 1).

Распределение ответов респондентов о причине иметь семью показывает доминанту позиции «чтобы быть счастливым», так считает каждый третий $(31,1$ \%). Далее значимыми позициями, примерно равными по популярности ответов, выступают следующие: «чтобы не быть одиноким» $(16,4 \%)$, «хочу быть рядом с человеком схожих взглядов» $(14,7 \%)$, «хочу иметь детей» $(14,5 \%)$.

Выбор семейного статуса респондентами обусловлен преимущественно моделью счастья, где понятие семьи имеет важное значение, семья выступает как важный атрибут счастья в тезаурусе респондентов. Важно также подчеркнуть, что дети определяются респондентами так же, как фактор семейственности, но лишь в ответах каждого седьмого респондента.

Распределение ответов на вопрос о причинах желания иметь детей далеко неоднозначное, есть ряд более значимых позиций, однако самая популярная из них не составляет более 17,2\%. Можно перечислить три наиболее популярных ответа, где процент выбравших составляет более 10: «чтобы мой род продолжился» $(17,2 \%)$, «дети - это продолжение меня, моего генетического фонда» $(13,7 \%)$, «люблю детей, хочу заниматься их воспитанием» $(12,3 \%)$.

Преимущественно, если обобщить ряд схожих позиций, ответы на данный вопрос сводятся к желанию респондентов продолжить свой род.

При наличии всех необходимых условий респонденты в большинстве хотели бы иметь двух детей (39,7\%), чуть в меньшей преференции - трех (26,2\%), всего лишь одного ребенка хотел бы иметь только каждый десятый респондент, все прочие позиции были выбраны менее чем в $5 \%$ случаев каждая.

Подавляющее большинство респондентов $(78,9 \%)$ выросли в семье, где были оба кровных родителя, проживающих в зарегистрированном браке. Каждый шестой испытал на себе развод родителей $(18,6 \%)$.

Две трети респондентов имеют братьев или сестер $(73,4 \%)$, в подавляющем большинстве это один брат или сестра $(58,8 \%)$, также треть респондентов имеет двух братьев или сестер $(27,0 \%)$.

В отношении помощи своим племянникам $23 \%$ респондентов сказали, что активно участвуют, общаются, гуляют, помогают в уходе.

У $75 \%$ респондентов в окружении нет детей, в жизни которых они бы принимали активное участие.

Отвечая на вопрос: «Живут ли с вами ваши родители или родители вашей супруги/ партнерши?», 13,0\% сказали, что живут их родители, и еще $4,7 \%$ - что живут родители супруги/партнерши, 81,9\% респондентов отметили, что не проживают совместно со своими родителями или родителями супруги/ партнерши.

В ответах респондентов отмечается участие родителей супругов в воспитании детей, однако не столь значительное. Примерно каждый десятый отмечает, что его родители или родители супруги «забирают ребенка из школы/садика» $(10,2 \%)$, «играют с ним» $(11,4 \%)$, «дают деньги» $(10,4 \%)$, «покупают игрушки» $(10,6 \%)$, «занимаются с ним» $(10,6 \%)$.

Отвечая на вопрос об образце воспитания, респонденты преимущественно склонны считать вариант воспитания их родителей, то, как их самих воспитывали, некоторым необходимым вариантом, вполне приемлемым для воспитания их собственных детей (47,8\% ответили «да, так же» и $39,1 \%$ - «не совсем так, как они»).

Преимущественно отличный метод воспитания избрали $13,1 \%$ респондентов, причем в своем выборе они руководствуются нежеланием повторять ошибки своих родителей. В этой связи наиболее популярными причинами выступают следующие: «мои родители уделяли мне мало времени, мне 
не хватало их любви» $(29,0 \%)$, «мои родители не поддерживали мои стремления, начинания, хобби, интересы» $(12,7 \%)$, «мои родители никогда не считались с моим мнением» $(11,9 \%)$.

Хотел бы походить на своего отца только каждый четвертый из отвечавших мужчин, $48,4 \%$ «в чем-то хотели бы походить, в чемто нет», но 26,4\% полностью отрицают свое желание походить на своего отца.

Среди значимых позиций образа отца респондентами отмечается: «он материально обеспечивал детей», «он был с сильным характером», «он давал советы детям». Важно подчеркнуть, что вместе с тем значимость позиций определяется менее чем $10 \%$ по каждой (см. рис. 2).

Более половины респондентов оценивают свои отношения с родителями как отлич- ные $(55,9 \%)$ и готовы пожелать подобные отношения всем. 13,5\% респондентов считают, что отношения с родителями обычные, они иногда созваниваются. Значима доля тех, кто выбрал позицию «другое», где определяется более 40 авторских вариаций, преимущественно констатирующих, что отношения были нормальными, но родителей сейчас уже нет в живых $(11,2 \%)$.

Подобные ответы свидетельствуют о вполне четком определении респондентами для себя характера отношений с родителями. Данные ответы важно описывать в контексте и прочих вопросов об отношениях в семье в детстве, а также вопросов касательно наличия преемственности в воспитании детей и построения семейных отношений. Ответ «отличные» в данном вопросе лишь свидетельствует о том, что респонденты определя-

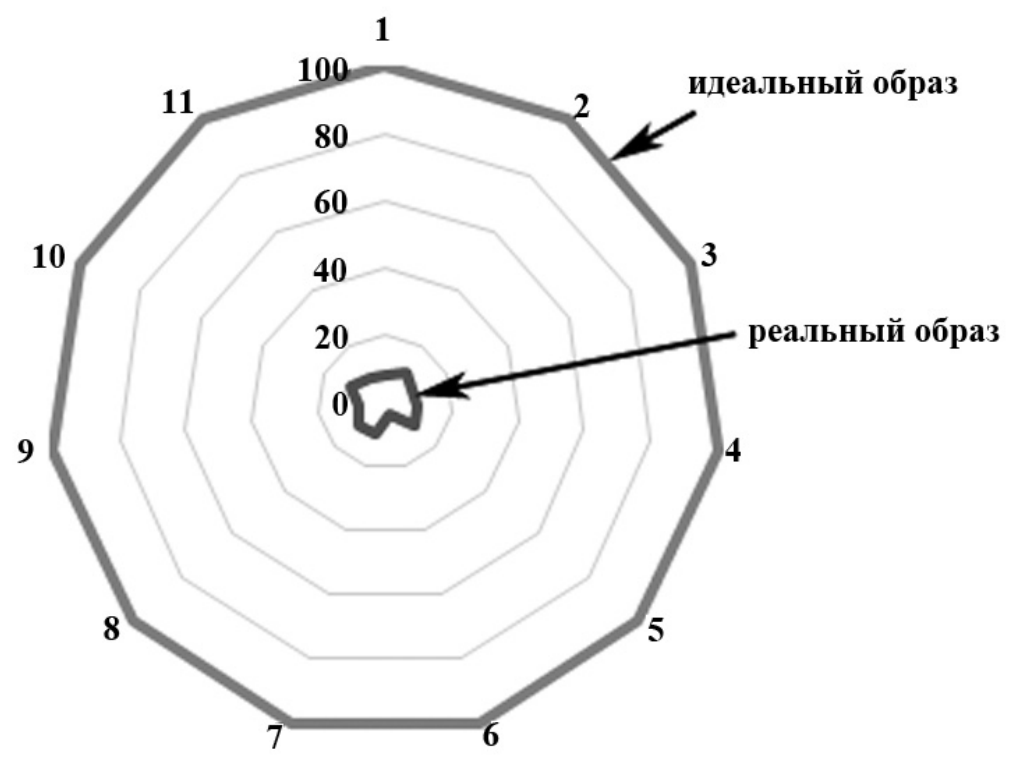

\begin{tabular}{|c|l|}
\hline 1 & он много времени проводил с детьми \\
\hline 2 & он материально обеспечивал детей \\
\hline 3 & он общался с детьми \\
\hline 4 & он был другом для детей \\
\hline 5 & он давал советы детям \\
\hline 6 & он занимал высокое положение в обществе \\
\hline 7 & он уважительно относился к супруге \\
\hline 8 & он уважительно относился к родителям \\
\hline 9 & к нему уважительно относилась супруга \\
\hline 10 & он был с сильным характером \\
\hline 11 & он занимался воспитанием детей \\
\hline
\end{tabular}

Рис. 2. «Образ отца» (соотношение максимальных и реальных оценок позиций, в \%) 
ют те отношения, которые у них сложились, как вполне приемлемые для себя.

Критериями тезауруса по ряду вопросов выступают понятия «взаимопомощи» и «взаимоучастия», однако доля значимости данных позиций в кросс-анализе вопросов-ответов мала.

Так, при определении степени соучастия респондента жизни дочери/сына отмечается чуть большая связь респондентов с дочерями, однако популярность выбора позиций «3 - часто/почти каждый день» отмечается в самом популярном варианте лишь у каждого пятого.

Оценки параллельных переменных исследования. В исследовании для определения возрастного семейного тезауруса был применен метод построения аллювиальной диаграммы (фазовой сетевой диаграммы), позволяющей определить изменения в структуре социально-экономических сетей заданных переменных в течение времени.
Переменные, присвоенные параллельным вертикальным осям в рамках исследования в распределении слева-направо, следующие: наличие детей (ответ: да, кровные); для чего Вам нужна семья? (ответ: хочу иметь детей); в какой семье Вы выросли? (ответ: у меня было (есть) оба кровных родителя, проживающих в зарегистрированном браке); Вы бы хотели быть похожим на своего отца (ответ: да, хотел бы походить во всем) (см. рис. 3).

Расчетные значения представлены блоками на каждой оси. Высота блока определяет размер кластера, а высота поля потока представляет размер компонентов, содержащихся в обоих блоках, связанных полем потока.

На основе рассмотренных переменных сформируем графическую интерпретацию возрастного семейного тезауруса. Графическая фиксация основных ценностных ориентиров позволяет утверждать максимальное их обеспечение в общем ценностном представлении молодых людей к возрастной

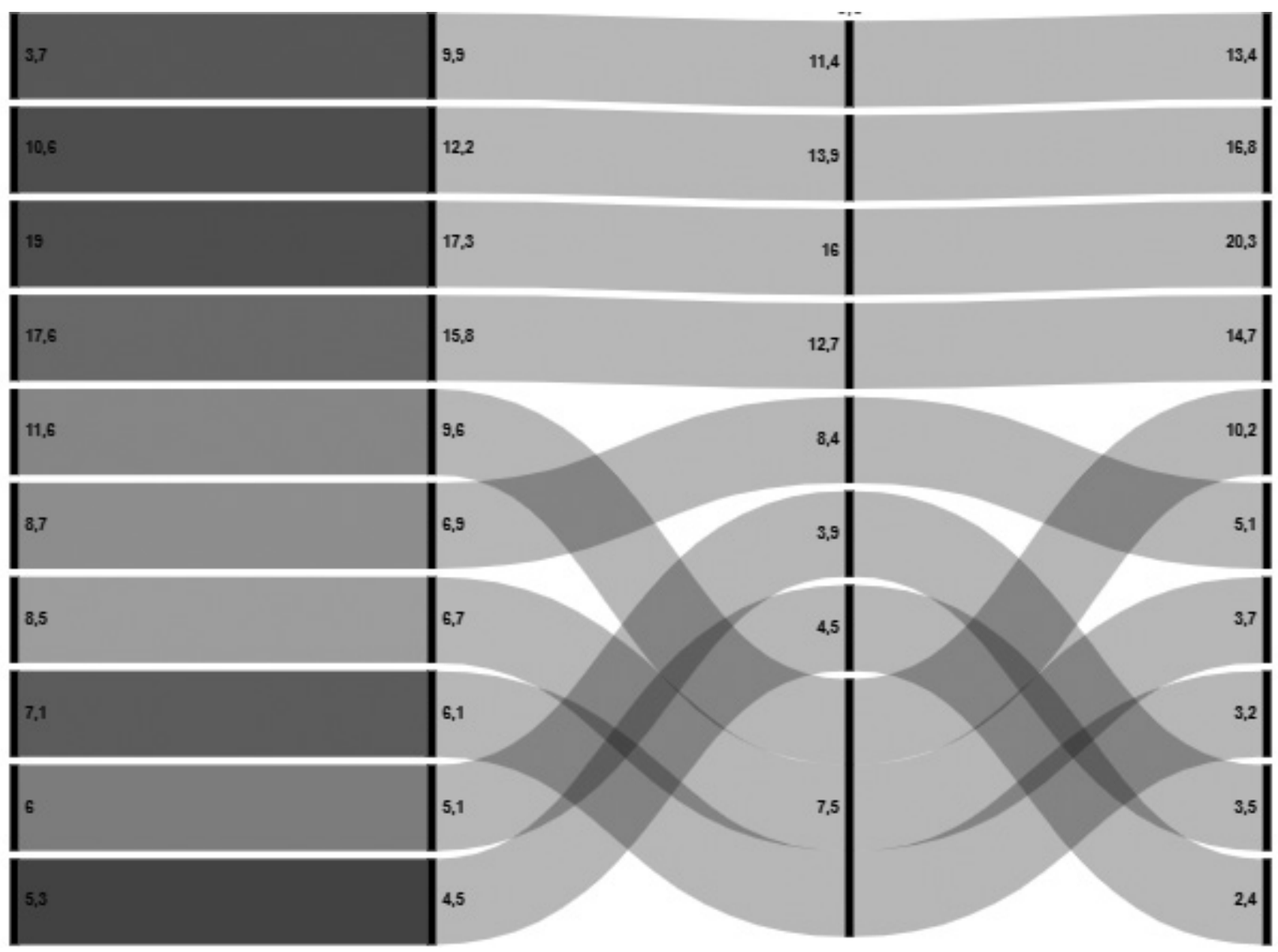

Рис. 3. Аллювиальные диаграммы возрастного семейного тезауруса 


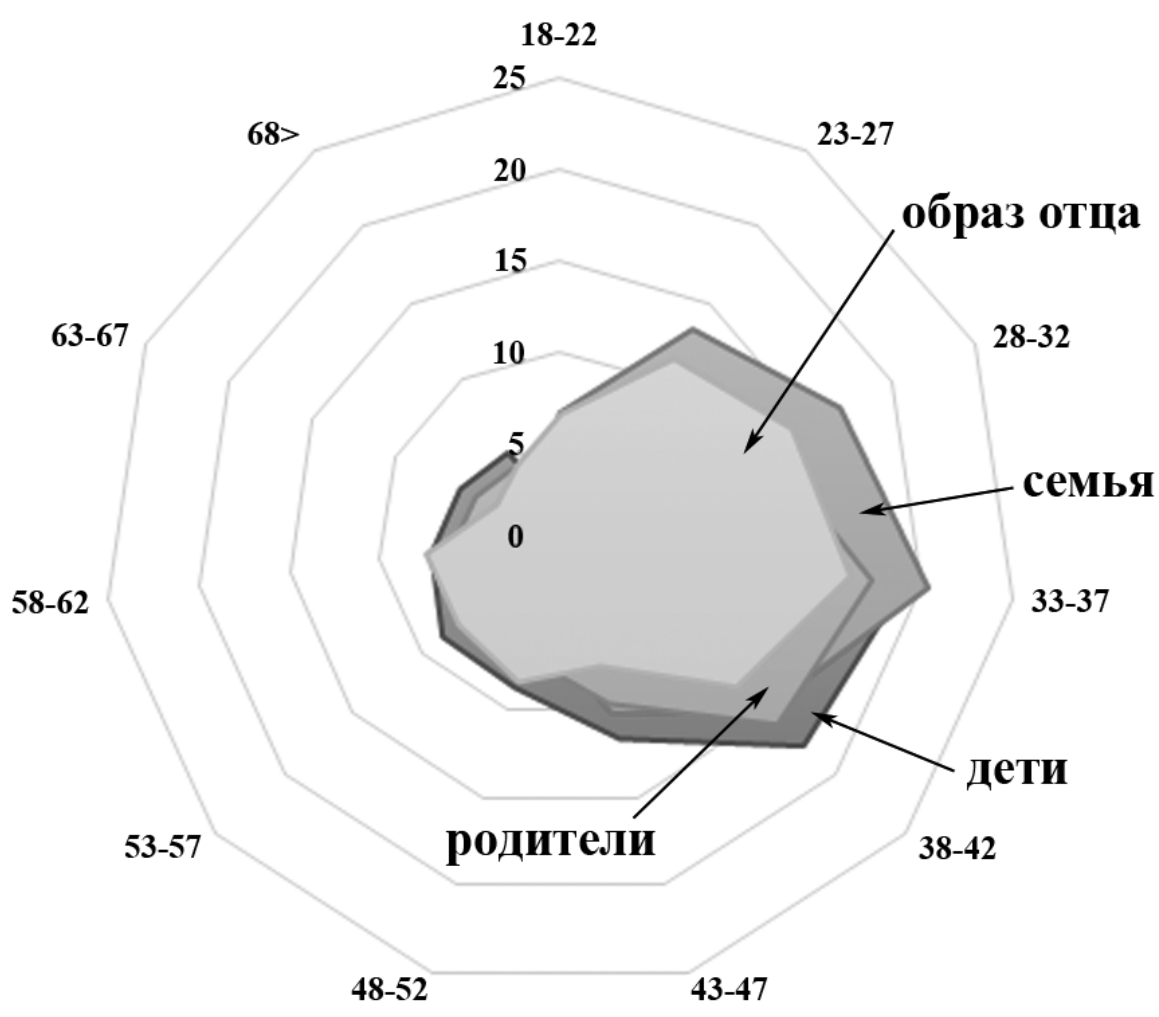

Рис. 4. Возрастной семейный тезаурус

группе «28-32 года», однако и далее данный процесс получает свое большее осознание и утверждение в особенно активной фазе до 38 лет (см. рис. 4).

Тезаурус молодой семьи. У трети респондентов в основе тезауруса семьи - сформированный разрыв отношений «родители - дети» с выраженной позицией-маркером «мои родители уделяли мне мало времени, мне не хватало их любви».

Из вопросов, касающихся детности, формируется тенденция, которая отчетливо отражает отсутствие явной корреляции между семейными представлениями респондентов и наличием детей, а также согласованности позиций по желанию и количеству детей с супругой/партнершей.

Разорванность причинно-следственных как прямых, так и обратных связей: «семья дети».

Полностью отрицают свое желание походить на отца $26,4 \%$ респондентов (притом, что $48,4 \%$ также выбрали неоднозначную позицию, ответив, что «в чем-то хотели бы походить, в чем-то нет»), то есть для более чем 3/4 отвечавших отец не представляет абсолютного образца в своем поведении.

Определяя позиции взаимоуважения и взаимопомощи как значимые для формирования отношений между своей семьей и семьями родителей (собственных и супруги/партнерши), респонденты склонны в основном подчеркивать свою связь со своими родителями, нежели с родителями супруги/ партнерши.

Каждый пятый определяет себя как отличного отца, каждый второй старается быть хорошим отцом по самоощущениям, не фиксируя при этом отчетливо идеала «хорошего отца» и определяя качества «хорошего отца» крайне размыто, но чуть более сводящимися к позициям справедливости и ответственности.

Критериями тезауруса по ряду вопросов выступают понятия «взаимопомощи» и «взаимоучастия», однако доля значимости данных позиций в кросс-анализе вопросов-ответов мала.

Оценивая значимость семьи в семейном тезаурусе респондентов, важно провести сравнение определения ими степени значимости работы и семьи в сопоставимых оцен- 
ках. Оцениваемые позиции характеризуются стабильной значимостью работы и маркерной значимостью семьи в отношении абсолютной позиции -5 баллов.

Заключение. Институт семьи у мужчин формируется преемственно, наделяется иерархичностью передаваемого авторитета образа главы семьи, формирующего иерархическую и ценностную устойчивость семейных отношений, что в своей системности и формирует «семейный тезаурус» как преемственную иерархическую систему взаимообусловленных ролей, подчиненных ценностно-авторитарному центру семьи носителю авторитетного семейного образца, передающего его в поколениях.

Данные исследования отражают разрыв «семейного тезауруса», утрату авторитарноценностной системы семейных отношений, что приводит к нивелированию ответственности, искажению форм семейных отношений, ориентации на ложные семейные ценности.

Восстановление семейного тезауруса является долгим историческим последовательным, системным процессом эволюционного характера, затрагивающим несколько поколений с сопутствующей общественной и социальной работой общественных институтов по формированию и поддержанию ценностно значимых семейных маркеров. Мерами оперативного воздействия должны стать меры регулирования семейной ответственности, в первую очередь по обеспечению детей, социальной и экономической защиты материнства и детства.

\section{Литература}

1. Word Values Survey Site [Электронный ресурс]. - Режим доступа: http:// www.worldvaluessurvey.org/wvs/articles/ folder_published/publication_587/files/ ChangingMassPriorities.pdf (Дата обращения: 29.01.2020).

2. Лапин Н.И. Функционально-ориентирующие кластеры базовых ценностей населения России и ее регионов // Социологические исследования. - 2010. - №1. - С. 28-36.

3. Луков В. А., Захаров Н.В. Ценностные ориентации российской молодежи // Знание. Понимание. Умение. - 2008. - №3.
4. Магун В. С. Базовые ценности - 2008: сходства и различия между россиянами и другими европейцами / В.С. Магун, М.Г. Руднев. - М.: Изд. дом Гос. ун-та - Высшей школы экономики, 2010. - $52 \mathrm{c}$.

5. Социальный портрет молодежи Российской Федерации: аналитический доклад / Комиссия по социальным вопросам и демографической политике Общественной палаты Российской Федерации. - М., 2011.

6. Социокультурные факторы национальной безопасности России: сб. науч. трудов / отв. ред. А.В. Костина. - М.: Изд-во Моск. гуманит. ун-та, 2015.

7. Тезаурус социологии. Кн. 2. Методология и методы социологических исследований: тематический словарь-справочник / под ред. Ж.Т. Тощенко. - М.: ЮНИТИ-ДАНА, 2013.

8. Тощенко Ж.Т. Фантомы российского общества. - М.: Центр социального прогнозирования и маркетинга, 2015.

9. Федотова Н.Н. Концепции идентичности в условиях нелинейной социокультурной динамики // Знание. Понимание. Умение. - 2013. - №2. - С. 52-62.

10. Чередниченко Г.А. Образовательные и профессиональные траектории российской молодежи (на материалах социологических исследований). - М.: Центр социального прогнозирования и маркетинга, 2014.

11. Чикагская социология: сб. переводов / РАН. ИНИОН. Центр социал. науч.-информ. исслед. Отд. социологии и социал. психологии; сост. и пер. В. Г. Николаев; отв. ред. Д. В. Ефременко. - М., 2015.

\section{References}

1. Word Values Survey Site [Jelektronnyj resurs]. - URL: http://www.worldvaluessurvey.org/wvs/articles/folder_published/publication_587/files/ChangingMassPriorities.pdf (Date accessed: 29.01.2020).

2. Lapin N.I. Funkcional'no-orientirujushhie klastery bazovyh cennostej naselenija Rossii i ee regionov [Functionally-orienting clusters of basic values of the population of Russia and its regions] // Sociologicheskie issledovanija [Sociological research]. - 2010. — №1. - Pp. 28-36.

3. Lukov V.A., Zaharov N.V. Cennostnye orientacii rossijskoj molodezhi [Value orienta- 
tions of Russian youth] // Znanie. Ponimanie. Umenie [Knowledge. Understanding. Skill]. 2008. — №3.

4. Magun V.S. Bazovye cennosti - 2008: shodstva i razlichija mezhdu rossijanami i drugimi evropejcami [Basic values - 2008: similarities and differences between Russians and other Europeans] / V.S. Magun, M.G. Rudnev. Moscow: Izd. dom Gos. un-ta — Vysshej shkoly jekonomiki, 2010. - $52 \mathrm{p}$.

5. Social'nyj portret molodezhi Rossijskoj Federacii: analiticheskij doklad [Social portrait of the youth of the Russian Federation: an analytical report] / Komissija po social'nym voprosam i demograficheskoj politike Obshhestvennoj palaty Rossijskoj Federacii [Commission on social Issues and demographic policy of the Public Chamber of the Russian Federation]. - Moscow, 2011.

6. Sociokul'turnye faktory nacional'noj bezopasnosti Rossii: sb. nauch. trudov [Sociocultural factors of national security of Russia: collection of scientific works] / in A. V. Kostina (eds.). - Moscow: Izd-vo Mosk. gumanit. un-ta, 2015.

7. Tezaurus sociologii. Kn. 2. Metodologija i metody sociologicheskih issledovanij: tematicheskij slovar'-spravochnik [Thesaurus of Sociology. Book 2. Methodology and methods of sociological research: a thematic dictionaryreference book] / in Zh. T. Toshhenko (eds.). Moscow: JuNITI-DANA, 2013.

8. Toshhenko Zh. T. Fantomy rossijskogo obshhestva [Phantoms of Russian society]. Moscow: Centr social'nogo prognozirovanija i marketinga, 2015.

9. Fedotova H. H. Koncepcii identichnosti $\mathrm{v}$ uslovijah nelinejnoj sociokul'turnoj dinamiki [Concepts of identity in the conditions of nonlinear socio-cultural dynamics] // Znanie. Ponimanie. Umenie [Knowledge. Understanding. Skill]. — 2013. — №2. - Pp. 52-62.

10. Cherednichenko G.A. Obrazovatel'nye i professional'nye traektorii rossijskoj molodezhi (na materialah sociologicheskih issledovanij) [Educational and professional trajectories of Russian youth (based on the materials of sociological research)]. - Moscow: Centr social'nogo prognozirovanija i marketinga, 2014.

11. Chikagskaja sociologija: sb. perevodov [Chicago Sociology: collection of translations]/ RAN. INION. Centr social. nauch.-inform. issled. Otd. sociologii i social. psihologii [Center for Social Science and Information Research. Department of Sociology and Social Sciences Psychology]; sost. i per. V.G. Nikolaev; in D. V. Efremenko (eds.). — Moscow, 2015.

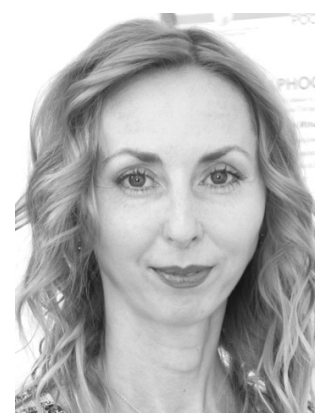

Ильдарханова Чулпан Ильдусовна - доктор социологических наук, директор Центра семьи и демографии Академии наук Республики Татарстан.

Ildarhanova Chulpan Ildusovna - Doctor of Sociological Sciences, Director of Family and Demography Center, Tatarstan Academy of Sciences.

420111, г. Казань, ул. Левобулачная, 36а

36a Levobulachnaya st., 420111, Kazan, Russia

E-mail: chulpanildusovna@gmail.com 


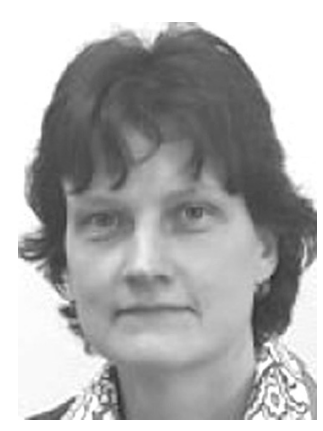

Гневашева Вера Анатольевна - доктор экономических наук, руководитель отдела воспроизводства трудовых ресурсов и занятости населения Института демографических исследований Федерального научно-исследовательского социологического центра РАН.

Gnevasheva Vera Anatolyevna - Doctor of Economic Sciences, Head of the Department of Reproduction of Labor Resources and Employment, Institute of Demographic Research of the Federal Research Sociological Center of the Russian Academy of Sciences.

19333, г. Москва, ул. Фотиевой, 6

6 Fotievoj st., 119333, Moscow, Russia

E-mail: vera_cos@rambler.ru 